\title{
Quebra de dormência de minitubérculos de batata ${ }^{1}$
}

\author{
Dormancy breaking of potato minitubers
}

\begin{abstract}
Marlova Benedetti ${ }^{2}$ Dilson Antônio Bisognin ${ }^{3}$ Fernanda Bastos Segatto ${ }^{4}$ Liege Camargo da Costa ${ }^{5}$ Maurício Guerra Bandinelli ${ }^{6}$ Auri Brackmann ${ }^{7}$
\end{abstract}

\section{RESUMO}

A quebra de dormência de batata-semente (Solanum tuberosum) é necessária em programas de melhoramento genético, na multiplicação de tubérculos livres de vírus e na produção comercial de batata quando o período entre a colheita e o próximo plantio é insuficiente para a brotação dos tubérculos. Um experimento foi conduzido com o objetivo de avaliar a eficácia de diferentes tratamentos para a quebra de dormência de minitubérculos de batata dos clones Macaca, de curta dormência, e SMIJ461-1, de longa dormência. Os tratamentos foram: testemunha, aspersão com etanol e ácido giberélico $(10 \mathrm{mg}$ $\left.\mathrm{L}^{-1}\right)$, abafamento com bissulfureto de carbono $\left(35 \mathrm{~mm} \mathrm{~m} \mathrm{~m}^{-3}\right)$ por $72 \mathrm{~h}$, aspersão com ácido giberélico (30 $\mathrm{mg} \mathrm{L}^{-1}$ ) seguido de abafamento por $72 \mathrm{~h}$, imersão com ácido 2-4 cloroetil fosfônico (840mg $\mathrm{L}^{-1}$ ) por $5 \mathrm{~s}$, e alternância de temperaturas (ciclos de sete dias a $4^{\circ} \mathrm{C}$ e sete dias a $20^{\circ} \mathrm{C}$ ). $\mathrm{O}$ delineamento experimental foi um trifatorial (clone $x$ quebra de dormência $x$ safra) no delineamento experimental inteiramente casualizado, com quatro repetições de dez minitubérculos. A resposta aos tratamentos variou entre clones e safras. A maior resposta dos tratamentos para a quebra de dormência foi com o clone Macaca. Os tratamentos com ácido giberélico foram os mais eficazes para a quebra de dormência de ambos os clones. A percentagem final de minitubérculos brotados do clone SMIJ461-1 foi baixa, necessitando de maiores estudos quanto à concentração e tempo de aplicação dos tratamentos.

Palavras-chave: Solanum tuberosum, brotação, semente.

\begin{abstract}
In some potato (Solanum tuberosum) grown areas, time between harvesting and planting is shorter than seed dormancy period. In these areas, dormancy breaking is necessary in breeding programs, virus-free seed production and commercial production fields. An experiment was carried out with the objective of evaluating the efficacy of different treatments to break dormancy of potato minitubers of Macaca, with short dormancy, and SMIJ461-1, with long dormancy. The treatments were: control, spraying with ethanol and giberellic acid $(10 \mathrm{mg}$ $\left.L^{-1}\right)$, suffocation with carbon disulfate $\left(35 \mathrm{~mm} \mathrm{~m}^{-3}\right)$ for $72 \mathrm{~h}$, spraying with giberellic acid $\left(30 \mathrm{mg} \mathrm{L}^{-1}\right)$ and suffocation for $72 \mathrm{~h}$, immersion with 2-4 chloroethyl phosphonic acid (840mg $\left.\mathrm{L}^{-1}\right)$ for $5 \mathrm{~s}$, and temperature cycles of seven days at $4^{\circ} \mathrm{C}$ and seven days at $20^{\circ} \mathrm{C}$. The experiment was a factorial (clone $x$ dormancy breaking $x$ grown season) in complete random design with four replications of ten minitubers. Treatment effects varied between clones and grown seasons. The major treatment effect of dormancy breaking was with 'Macaca'. The highest efficacy of dormancy breaking was with giberellic acid treatments in both clones. The percentage of sprouted minitubers of SMIJ461-1 was lower than Macaca. Additional studies with treatment concentration and application time are necessary with the SMIJ461-1 clone.
\end{abstract}

Key words: Solanum tuberosum, sprouting, seeds.

${ }^{1}$ Parte da dissertação de mestrado do primeiro autor apresentada ao Programa de Pós-graduação em Agronomia (PPGA).

${ }^{2}$ Engenheiro Agrônomo, Mestre em Agronomia, Departamento de Fitotecnia, Universidade Federal de Santa Maria (UFSM), Bolsista do Conselho Nacional de Desenvolvimento Científico e Tecnológico (CNPq).

${ }^{3}$ Engenheiro Agrônomo, PhD, Professor do Departamento de Fitotecnia, UFSM, 97105-900, Camobi, Santa Maria, RS. E-mail: dilsonb@smail.ufsm.br. Autor para correspondência.

${ }^{4}$ Biólogo, Mestre em Agronomia, Departamento de Fitotecnia, UFSM.

${ }^{5}$ Engenheiro Agrônomo, Mestre em Agronomia, Doutorando do PPGA, UFSM

${ }^{6}$ Estudante do Curso de Agronomia da UFSM, Bolsista de iniciaçäo científica da UFSM.

${ }^{7}$ Engenheiro Agrônomo, Doutor, Professor do Departamento de Fitotecnia, UFSM. 


\section{INTRODUÇÃO}

A dormência da batata-semente (Solanum tuberosum) pode ser definida como o estádio fisiológico em que não ocorre o crescimento do broto, mesmo em condições ideais (FONTES \& FINGER, 1999). As cultivares podem diferir marcadamente na duração da dormência, embora estas diferenças possam ser devidas à idade dos tubérculos (BEUKEMA \& VAN DER ZAAG, 1979). Apesar da dormência ser vantajosa para o armazenamento dos tubérculos (PÓGI \& BRINHOLI, 1995), a quebra é necessária em programas de melhoramento genético, na multiplicação de tubérculos livres de vírus e na produção comercial de batata em regiões onde o cultivo é feito em duas safras anuais e o período entre a colheita e o próximo plantio é insuficiente para a quebra natural da dormência dos tubérculos (BISOGNIN et al., 1996). A primeira geração clonal de melhoramento e a multiplicação inicial de batata-semente normalmente são feitas a partir de um número reduzido de tubérculos, predominantemente minitubérculos, que normalmente apresentam maiores níveis de dormência (BEUKEMA \& VAN DER ZAAG, 1979).

Vários métodos têm sido utilizados para reduzir o período de dormência dos tubérculos. O ácido giberélico promove o aumento do nível endógeno de giberelinas, resultando na quebra de dormência dos tubérculos (RABIE et al., 1992). O ácido giberélico associado ao abafamento estimula a brotação dos tubérculos, devido ao aumento da temperatura, diminuição da concentração de oxigênio e aumento da concentração de gás carbônico (SCHOLTE, 1990). A aplicação de ácido giberélico por aspersão nos tubérculos logo após a colheita acelerou a brotação, aumentou o número de hastes e tubérculos e o rendimento de tubérculos (BISOGNIN et al., 1998). O ácido giberélico (10mg L-1) combinado com etanol estimulou a brotação precoce de tubérculos de batata da cv. Bintje e resultou em um aumento expressivo no número e comprimento dos brotos aos 18 dias (LUND et al, 2001). O abafamento dos tubérculos com bissulfureto de carbono também tem apresentado bons resultados, devendo-se tomar cuidados especiais com a dose e o tempo de aplicação para cada cultivar, já que, em algumas situações, especialmente em doses muito altas, pode ocasionar o apodrecimento dos tubérculos (BEUKEMA \& VAN DER ZAAG, 1979; SCHOLTE, 1990).

Também é possível que o etileno estimule o aumento da síntese de giberelinas e o surgimento de enzimas requeridas para a quebra de dormência. Dependendo da concentração e duração da exposição, o etileno exógeno pode aumentar ou diminuir a brotação dos tubérculos (SUTTLE, 1998). A superioridade do tratamento com o ácido 2-4-cloroetilfosfônico (ethephon) em relação ao ácido giberélico e ao bissulfureto de carbono, aliada a sua facilidade de aplicação, justificou a sua utilização na quebra de dormência de tubérculos da cv. Marijke (AYUB et al., 1999).

A temperatura de armazenamento é um importante fator que influencia na duração do período de dormência. A elevação da temperatura de armazenamento de 10 para $20^{\circ} \mathrm{C}$ mostrou ter mais efeito na quebra de dormência do que a elevação 2 para $10^{\circ} \mathrm{C}$. Em certos casos, a flutuação da temperatura de armazenamento reduz mais o período de dormência do que temperaturas constantemente altas. A temperatura também influencia o crescimento dos brotos. Temperaturas entre 16 e $20^{\circ} \mathrm{C}$ parecem ser mais adequadas para o crescimento dos brotos (BEUKEMA \& VAN DER ZAAG, 1979). Dentro de certos limites, a temperatura exerce um efeito quantitativo na duração da dormência enquanto o crescimento dos tecidos exibe uma resposta linear à temperatura (SUTTLE, 1995).

O objetivo deste trabalho foi avaliar a eficácia de diferentes tratamentos para a quebra de dormência de minitubérculos de clones de batata com diferentes níveis de dormência.

\section{MATERIAL E MÉTODOS}

O experimento foi conduzido nos telados e laboratórios do Programa de Genética e Melhoramento de Batata do Departamento de Fitotecnia da Universidade Federal de Santa Maria. Plântulas micropropagadas in vitro foram adaptadas e plantadas em canteiros de um telado coberto com polietileno para a produção dos minitubérculos durante a safra de 2002 e a safrinha de 2003. Os minitubérculos foram classificados e aqueles com diâmetro entre 10 e 23mm receberam os tratamentos dia 09 de janeiro de 2003 (safra) e dia 23 de julho de 2003 (safrinha).

Foram utilizados os clones Macaca, de curta dormência, e SMIJ461-1, de longa dormência. Os tratamentos foram: testemunha, aspersão com uma solução de etanol e ácido giberélico $\left(10 \mathrm{mg} \mathrm{L}^{-1}\right)$, abafamento com bissulfureto de carbono (35 $\mathrm{mm} \mathrm{m}^{-3}$ ) por $72 \mathrm{~h}$, aspersão com ácido giberélico (30 $\mathrm{mg} \mathrm{L}^{-1}$ ) seguido de abafamento por $72 \mathrm{~h}$, imersão com ácido 24 cloroetil fosfônico $\left(840 \mathrm{mg} \mathrm{L}^{-1}\right)$ por 5 s, e alternância de temperaturas. A fonte de ácido giberélico usada foi o produto comercial Progibb ${ }^{\circledR}$. A aspersão foi feita até a completa cobertura da superfície dos minitubérculos, que após foram mantidos sobre papel para secagem. 
O abafamento foi obtido através do uso de recipientes de vidro, com volume de 5L, hermeticamente fechados, onde a massa de minitubérculos de aproximadamente 60 gramas permaneceu durante o tempo prédeterminado. Os tubérculos tratados permaneceram durante dois meses em câmara frigorífica climatizada na temperatura de $20^{\circ} \mathrm{C}$ e umidade relativa aproximada de 85\%. A alternância de temperaturas foi realizada em ciclos, em que os minitubérculos permaneceram sete dias a temperatura de $4^{\circ} \mathrm{C}$ e sete dias a $20^{\circ} \mathrm{C}$. O experimento foi um trifatorial (clone $\mathrm{x}$ quebra de dormência x safra) no delineamento experimental inteiramente casualizado, com quatro repetições de dez minitubérculos.

Foram realizadas contagens quinzenais do número de brotos com pelo menos $2 \mathrm{~mm}$ de comprimento em cada tubérculo e da percentagem de tubérculos brotados. Com os dados originais, foram calculadas as áreas abaixo da curva de progressão (BISOGNIN et al., 2002). Semanalmente foi medida a produção de etileno, por cromatografia gasosa, e a percentagem de $\mathrm{CO}_{2}$, através de um analisador de gases, conforme sugerido por BRACKMANN et al. (2002). Aos 60 dias após a aplicação dos tratamentos, época em que o estádio fisiológico dos tubérculos deveria ser adequado para o próximo plantio, os minitubérculos foram plantados em canteiros sob telado no espaçamento de $0,10 \times 0,10 \mathrm{~m}$ para as avaliações de planta. Foram avaliadas a percentagem de tubérculos com plantas emergidas e a altura média de plantas, quando a emergência das plântulas se estabilizou.

Os dados foram submetidos à análise da variância (teste F) e as médias comparadas pelo teste de Duncan. Para a análise estatística, os dados de contagem foram transformados para raiz quadrada de $\mathrm{x}+0,5$ e os de percentagem para arco seno de raiz quadrada de $\mathrm{x} / 100$, utilizando $5 \%$ de probabilidade de erro.

\section{RESULTADOS E DISCUSSÃO}

Os minitubérculos tratados com bissulfureto de carbono tiveram respiração mais alta durante todo o período de armazenamento, sendo que, em geral, a respiração foi maior logo após a colheita dos minitubérculos, no início do armazenamento e voltou a subir no final do período de armazenamento no clone Macaca (Figura 1A e 1B). No clone SMIJ461-1, o bissulfureto também promoveu maior respiração por parte dos minitubérculos, porém o aumento desta no final do período de armazenamento não foi tão pronunciado (Figura 1C e 1D). Quanto ao etileno na safra, foram observados dois picos de produção, sendo um aos 28 dias após o tratamento e outro no final do período de armazenamento (60 dias) para os tratamentos da safra (Figura 2A e 2C). Em geral, o tratamento com ethephon teve maior produção de etileno durante todo o período de armazenamento, principalmente no clone Macaca (Figura 2A e 2B). Na safrinha, a produção de etileno foi menor do que na safra e não foi observado nenhum pico de produção como na avaliação na safra. Apesar de se encontrarem em estádio de dormência, os tubérculos de batata estão ainda metabolicamente ativos. A respiração está associada com esta atividade metabólica e é requerida para a manutenção celular. A taxa respiratória geralmente cai de um alto valor na colheita para um nível basal muito baixo dentro de poucas semanas (WILTSHIRE \& COBB, 1996). Este padrão foi verificado nesse trabalho em ambos clones e safras.

A interação clone $x$ quebra de dormência $x$ safra foi significativa para todas as variáveis analisadas (Tabelas 1, 2 e 3). Para o clone Macaca, a progressão do número de brotos por tubérculo foi maior nos minitubérculos tratados com ácido giberélico e etanol na safra, enquanto que, na safrinha, o tratamento com bissulfureto foi superior (Tabela 1). Para o clone SMIJ461-1, houve diferença significativa entre os tratamentos apenas na safra, onde o tratamento com alternância de temperaturas foi inferior a todos os demais. O tratamento com bissulfureto de carbono no clone SMIJ461-1 causou o apodrecimento de todos os minitubérculos na safrinha, não permitindo realizar nenhuma avaliação. Este efeito provavelmente foi devido à aplicação logo após a colheita, quando a casca dos tubérculos ainda não estava firme, conforme já observado em outros trabalhos (BEUKEMA \& VAN DER ZAAG, 1979; SCHOLTE, 1990). No entanto, o tratamento com bissulfureto de carbono foi superior aos demais e promoveu a quebra de dormência dos minitubérculos de SMIJ461-1 na safra. Para a progressão da percentagem de tubérculos brotados para o clone Macaca na safra, os tratamentos com ácido giberélico em ambas associações (etanol ou abafamento) foram superiores, enquanto que, na safrinha, o tratamento com bissulfureto de carbono teve resultado superior aos demais. Já no clone SMIJ461-1 apenas a testemunha, o ethephon e a alternância de temperaturas foram inferiores aos demais. Na safrinha, a testemunha foi superior aos demais tratamentos.

No final do período de armazenamento, os tratamentos à base de ácido giberélico, na safra, e o bissulfureto de carbono, na safrinha, apresentaram maior número de brotos por tubérculo no clone Macaca (Tabela 2). Todos os tratamentos foram superiores à 


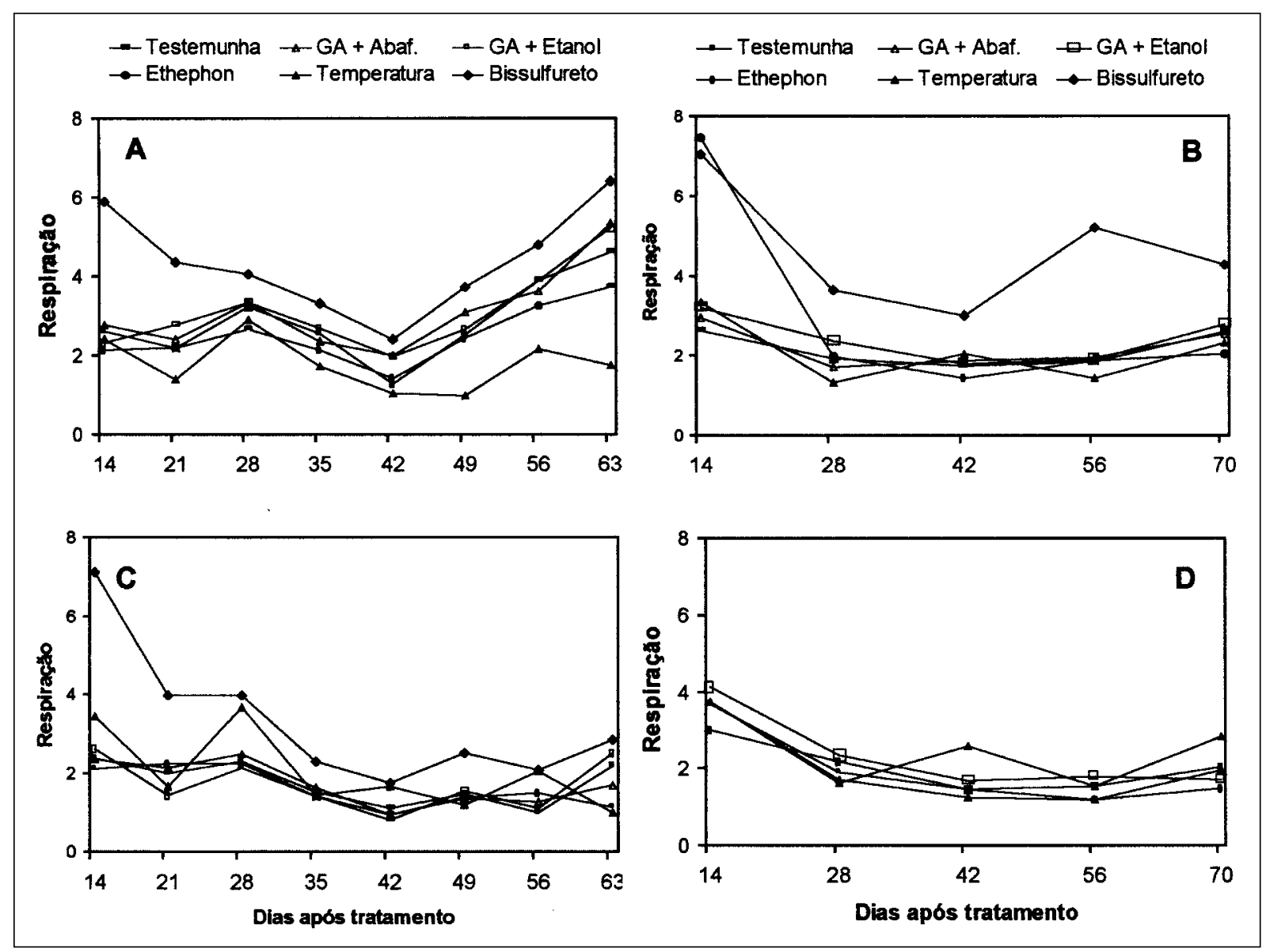

Figura 1 - Evolução da respiração em função de diferentes tratamentos para a quebra de dormência de minitubérculos de Macaca (A e B) e SMIJ461-1 (C e D) durante a safra (A e C) e safrinha (B e D). Santa Maria, RS. 2003.

testemunha na safra e não diferiram da testemunha em número de brotos por tubérculo no clone SMIJ461-1. Com exceção do tratamento de alternância de temperatura na safra, todos os tratamentos promoveram a quebra de dormência (80\% de tubérculos brotados) no clone Macaca. O bissulfureto de carbono foi o único tratamento na safra e nenhum tratamento na safrinha promoveu a quebra de dormência de minitubérculos do clone SMIJ461-1. A brotação dos tubérculos verificada aos 60 dias após a aplicação dos tratamentos pode explicar o pico de respiração e etileno no final do período de armazenamento dos minitubérculos produzidos durante a safra. Além disso, este pico de respiração e etileno somente foi observado com o abafamento com bissulfureto de carbono, o tratamento que apresentou a maior percentagem de tubérculos brotados e um dos maiores números de brotos por tubérculo.

A percentagem de tubérculos com plantas emergidas no clone Macaca foi maior nos minitubérculos tratados com ácido giberélico na safra e ácido giberélico combinado com abafamento na safrinha (Tabela 3). Ocorreu emergência de plantas em mais de $80 \%$ dos tubérculos do clone SMIJ461-1 tratados com bissulfureto de carbono. O tratamento com ácido giberélico associado ao abafamento promoveu, em termos absolutos, a maior altura média de plantas no clone Macaca na safrinha, porém este tratamento diferiu apenas da testemunha e da alternância de temperaturas. A alternância de temperaturas foi superior ao ácido giberélico mais etanol e ethephon e não diferiu dos demais tratamentos no clone SMIJ461-1 quanto à altura média de plantas na safra. A maior altura de plantas no clone SMIJ4611 na safrinha foi obtida com minitubérculos tratados com ácido giberélico mais etanol, sendo este superior ao ethephon e à alternância de temperaturas.

O efeito do ácido giberélico na quebra de dormência depende do nível endógeno de giberelinas, fazendo com que a eficácia da aplicação seja maior em

Ciência Rural, v.35, n.1, jan-fev, 2005. 


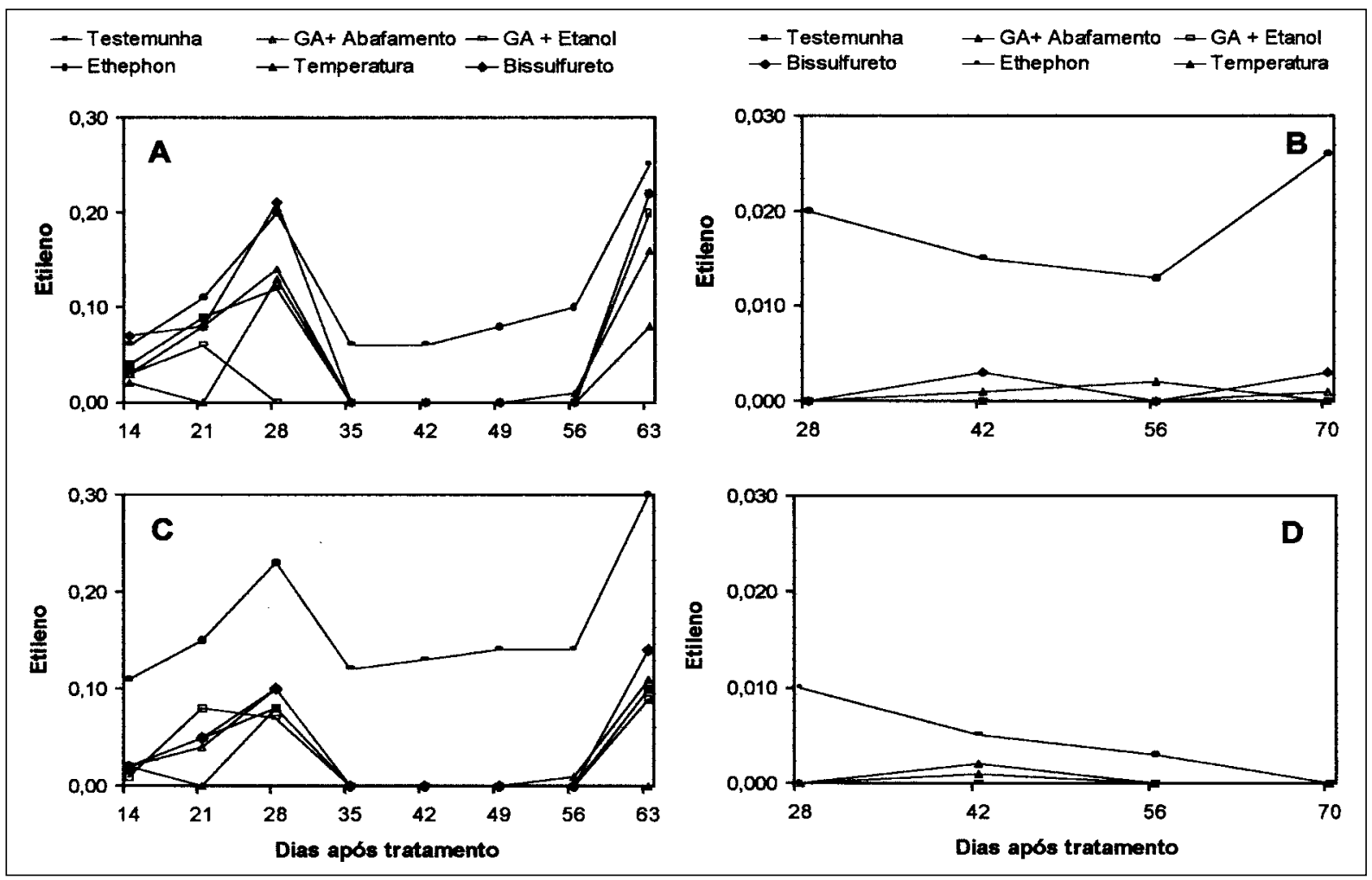

Figura 2 - Evolução do etileno em função de diferentes tratamentos para a quebra de dormência de minitubérculos de Macaca (A e B) e SMIJ461-1 (C e D) durante a safra (A e C) e safrinha (B e D). Santa Maria, RS. 2003.

Tabela 1 - Área abaixo da curva da progressão do número de brotos por tubérculo e percentagem de tubérculos brotados em função de diferentes tratamentos para a quebra de dormência de dois clones de batata. Santa Maria, RS. 2003.

\begin{tabular}{|c|c|c|c|c|}
\hline \multirow{3}{*}{ Tratamentos $^{1}$} & \multicolumn{2}{|c|}{ Масаса } & \multicolumn{2}{|c|}{ SMIJ461-1 } \\
\hline & Safra & Safrinha & Safra & Safrinha \\
\hline & \multicolumn{4}{|c|}{ Progressão do número de brotos por tubérculo } \\
\hline GA + Etanol & $217,7 a^{2}$ & $124,6 b$ & $36,7 a$ & 6,0a \\
\hline GA + Abafamento & $204,6 b$ & $81,8 \mathrm{~cd}$ & $38,6 a$ & $6,7 a$ \\
\hline Bis. de carbono & $153,30 \mathrm{c}$ & $152,4 a$ & $36,6 a$ & - \\
\hline Ethephon & $124,9 \mathrm{~d}$ & $93,7 \mathrm{c}$ & $32,7 a$ & $4,1 \mathrm{a}$ \\
\hline Testemunha & $99,7 \mathrm{e}$ & $71,0 \mathrm{~d}$ & $27,2 \mathrm{a}$ & $7,6 a$ \\
\hline Temperatura & $60,4 \mathrm{f}$ & $44,2 \mathrm{e}$ & $9,9 \mathrm{~b}$ & $6,3 a$ \\
\hline $\begin{array}{l}\text { Média } \\
\text { CV (\%) }\end{array}$ & 143,4 & 94,6 & 30,3 & 5,1 \\
\hline \multicolumn{5}{|c|}{ Progressão da percentagem de tubérculos brotados } \\
\hline GA + Etanol & $5025,0 \mathrm{a}$ & $3037,5 b$ & $1068,7 \mathrm{ab}$ & $512,5 b$ \\
\hline GA + Abafamento & $4668,7 a$ & $2687,5 b$ & $1275,0 \mathrm{a}$ & $543,8 \mathrm{~b}$ \\
\hline Bis. de carbono & $3647,6 \mathrm{~b}$ & $3437,5 a$ & $1029,2 \mathrm{ab}$ & - \\
\hline Ethephon & $3562,5 \mathrm{~b}$ & $2950,0 \mathrm{~b}$ & $718,7 \mathrm{bc}$ & $375,0 \mathrm{~b}$ \\
\hline Testemunha & $2775,0 \mathrm{c}$ & $2862,5 b$ & $290,6 \mathrm{~d}$ & 737,4 a \\
\hline Temperatura & $1875,0 \mathrm{~d}$ & 2187,5 c & $543,8 \mathrm{~cd}$ & $425,0 \mathrm{~b}$ \\
\hline Média & 3592,3 & 2860,4 & 821,0 & 524,1 \\
\hline CV (\%) & \multicolumn{4}{|c|}{14,47} \\
\hline
\end{tabular}

${ }^{1} \mathrm{GA}=$ aspersão com ácido giberélico na concentração $\left(\mathrm{mg} \mathrm{L}^{-1}\right)$ indicada. Bis. = bissulfureto.

${ }^{2}$ Tratamentos com médias não seguidas pela mesma letra nas colunas diferem entre si pelo teste de Duncan a 5\% de probabilidade de erro.

Ciência Rural, v.35, n.1, jan-fev, 2005. 
Tabela 2 - Número de brotos por tubérculo e percentagem de tubérculos brotados no final do período de armazenamento (60 dias) em função de diferentes tratamentos para a quebra de dormência de dois clones de batata. Santa Maria, RS. 2003.

\begin{tabular}{|c|c|c|c|c|}
\hline \multirow{3}{*}{ Tratamentos $^{1}$} & \multicolumn{2}{|c|}{ Масаса } & \multicolumn{2}{|c|}{ SMIJ461-1 } \\
\hline & Safra & Safrinha & Safra & Safrinha \\
\hline & \multicolumn{3}{|c|}{ Número de brotos por tubérculo } & \\
\hline Bissul. carbono & $5,9 a^{2}$ & 6,9a & $1,27 a$ & - \\
\hline GA + Abafamento & $5,8 a$ & 3,7cd & $1,10 \mathrm{a}$ & $0,41 \mathrm{a}$ \\
\hline GA + Etanol & $5,6 a$ & $4,5 b$ & 0,80ab & $0,40 \mathrm{a}$ \\
\hline Ethephon & $4,6 b$ & 3,9bc & 0,94ab & $0,25 a$ \\
\hline Testemunha & $3,9 c$ & $3,2 \mathrm{~d}$ & $0,32 b$ & $0,38 \mathrm{a}$ \\
\hline Temperatura & $1,9 \mathrm{~d}$ & $2,2 \mathrm{e}$ & $1,12 \mathrm{a}$ & $0,33 \mathrm{a}$ \\
\hline Média & 4,6 & 4,1 & 0,92 & 0,35 \\
\hline CV (\%) & & & & \\
\hline \multicolumn{5}{|c|}{ Percentagem de tubérculos brotados } \\
\hline Bissul. carbono & $100,0 \mathrm{a}$ & $100,0 \mathrm{a}$ & $81,7 \mathrm{a}$ & - \\
\hline GA + Etanol & $100,0 \mathrm{a}$ & $100,0 \mathrm{a}$ & $47,5 \mathrm{c}$ & $30,0 \mathrm{a}$ \\
\hline GA + Abafamento & $97,5 a$ & 98,3a & $60,0 \mathrm{~b}$ & 27,3ab \\
\hline Ethephon & $95,0 \mathrm{a}$ & $100,0 \mathrm{a}$ & $54,2 \mathrm{bc}$ & 23,3ab \\
\hline Testemunha & $90,0 \mathrm{a}$ & $98,3 a$ & $23,7 d$ & 25,0ab \\
\hline Temperatura & $70,0 \mathrm{~b}$ & $85,0 \mathrm{~b}$ & $52,5 \mathrm{bc}$ & $16,7 \mathrm{~b}$ \\
\hline Média & 92,1 & 96,9 & 53,3 & 24,4 \\
\hline CV (\%) & \multicolumn{4}{|c|}{12,24} \\
\hline
\end{tabular}

${ }^{1} \mathrm{GA}=$ aspersão com ácido giberélico. Bis. = bissulfureto.

${ }^{2}$ Tratamentos com médias não seguidas pela mesma letra nas colunas diferem entre si pelo teste de Duncan a 5\% de probabilidade de erro.

Tabela 3 - Percentagem de tubérculos com plantas emergidas e altura média de plantas (cm) em função de diferentes tratamentos para a quebra de dormência de dois clones de batata. Santa Maria, RS. 2003.

\begin{tabular}{|c|c|c|c|c|}
\hline \multirow{2}{*}{ Tratamentos $^{1}$} & \multicolumn{2}{|c|}{ Мacaca } & \multicolumn{2}{|c|}{ SMIJ461-1 } \\
\hline & Safra & Safrinha & Safra & Safrinha \\
\hline \multicolumn{5}{|c|}{ Percentagem de tubérculos com plantas emergidas } \\
\hline GA + Abafamento & $80,6 a^{2}$ & 93,3a & $55,5 b$ & $42,5 a$ \\
\hline GA + Etanol & $80,6 a$ & $51,7 \mathrm{~b}$ & $30,4 b$ & 33,3a \\
\hline Bissul. carbono & 69,4ab & $45,0 \mathrm{~b}$ & $86,1 \mathrm{a}$ & - \\
\hline Ethephon & $61,1 \mathrm{ab}$ & $35,0 \mathrm{bc}$ & $52,8 b$ & 33,3a \\
\hline Testemunha & $44,4 \mathrm{bc}$ & $13,3 \mathrm{~cd}$ & $31,2 b$ & $41,7 \mathrm{a}$ \\
\hline Temperatura & $30,5 c$ & $6,7 \mathrm{~d}$ & $52,8 \mathrm{~b}$ & $38,3 a$ \\
\hline Média & 61,1 & 40,8 & 51,5 & 37,8 \\
\hline CV (\%) & & & & \\
\hline \multicolumn{5}{|c|}{ tura média de plantas } \\
\hline GA + Abafamento & $9,3 a$ & $13,0 \mathrm{a}$ & $15,0 \mathrm{ab}$ & 13,8ab \\
\hline GA + Etanol & $8,1 \mathrm{a}$ & $6,4 \mathrm{ab}$ & $8,2 b$ & $18,6 a$ \\
\hline Bissul. carbono & $6,8 a$ & 8,3ab & $15,6 a b$ & - \\
\hline Temperatura & $6,1 \mathrm{a}$ & $4,0 \mathrm{~b}$ & $19,5 a$ & 7,9bc \\
\hline Testemunha & $4,8 a$ & $2,9 b$ & $16,5 \mathrm{ab}$ & $10,8 a b$ \\
\hline Ethephon & $4,8 \mathrm{a}$ & $7,0 \mathrm{ab}$ & $8,4 \mathrm{~b}$ & $5,9 \mathrm{bc}$ \\
\hline Média & 6,6 & 6,9 & 13,9 & 11,4 \\
\hline CV (\%) & \multicolumn{4}{|c|}{60,02} \\
\hline
\end{tabular}

${ }^{1} \mathrm{GA}=$ aspersão com ácido giberélico na concentração $\left(\mathrm{mg} \mathrm{L}^{-1}\right)$ indicada. Bis= Bissulfureto.

${ }^{2}$ Tratamentos com médias não seguidas pela mesma letra nas colunas diferem entre si pelo teste de Duncan a $5 \%$ de probabilidade de erro.

Ciência Rural, v.35, n.1, jan-fev, 2005. 
cultivares de menor dormência (BISOGNIN et al., 1998), o que justifica a maior resposta do clone Macaca aos tratamentos com ácido giberélico comparada com o clone SMIJ461-1. A associação do ácido giberélico com o etanol mostrou-se bastante eficaz na quebra de dormência, propiciando o tratamento dos tubérculos com uma menor quantidade de ácido giberélico e não necessitando de abafamento. O etanol apresentou um efeito sinergístico com o ácido giberélico no estímulo da brotação (LUND et al.,2001) e aumentou a brotação de gemas na cultivar Monte Bonito, principalmente logo após a colheita (CONCEIÇÃO et al.,1999). A alternância entre as temperaturas de 4 e $20^{\circ} \mathrm{C}$ não foi eficaz para promover a quebra de dormência, o que, de certa forma, contraria resultados obtidos por outros autores ( WURR \& ALLEN, 1976; TURNBULL \& HANKE, 1985, PÓGI \& BRINHOLI, 1995).

Esse trabalho mostrou claramente que há uma grande diferença quanto ao comportamento e quebra de dormência entre clones e épocas de cultivo. Com exceção da altura média de plantas, os tratamentos foram mais eficazes para a quebra de dormência do clone de curta dormência (Macaca) e de minitubérculos produzidos durante a safra. Esses resultados confirmam que a dormência dos tubérculos é uma característica genética (LECLERC et al., 1995) e muito influenciada pelo ambiente (BEUKEMA \& VAN DER ZAAG, 1979), pois a duração da dormência de grupos de tubérculos produzidos em condições ambientais controladas diferiu entre anos de cultivo e cultivares (ITTERSUM, 1992). Dentre as condições ambientais, a temperatura tem uma grande influência na duração da dormência. Tubérculos produzidos em altas temperaturas, particularmente no final do período de crescimento, apresentam menor dormência do que os produzidos em baixas temperaturas (BEUKEMA \& VAN DER ZAAG, 1979), explicando a maior eficácia dos tratamentos para a quebra de dormência dos minitubérculos produzidos durante a safra.

Os tratamentos de quebra de dormência foram mais eficazes para o clone Macaca do que para SMIJ461-1. Em Macaca, os tratamentos que promoveram maior número de brotos por tubérculo e maior percentagem de tubérculos brotados foram os com ácido giberélico. Portanto, estes resultados sugerem que o uso de ácido giberélico em minitubérculos de batata é eficaz para a quebra de dormência de clones com curta dormência. Estudos mais detalhados serão necessários quanto à concentração e tempo de aplicação dos tratamentos e de armazenamento visando a uma maior percentagem final de tubérculos brotados do clone SMIJ461-1. A eliminação de clones de longa dormência nas primeiras gerações clonais é um objetivo importante de um programa de melhoramento que visa desenvolver novas cultivares adaptadas a dois cultivos anuais, sendo que métodos para a quebra de dormência à base de ácido giberélico podem ser calibrados para esta finalidade.

\section{REFERÊNCIAS BIBLIOGRÁFICAS}

AYUB, R.A. et al. Ácido giberélico, bissulfureto de carbono e ácido 2-4 cloroetil fosfônico e a dormência e produtividade de tubérculos de batata. Scientia Agrícola, v.56, n.4, p.10151018, 1999

BEUKEMA, H.P.; VAN DER ZAAG, D.E. Potato improvement: some factors and facts. Wageningen : International Agricultural Centre, 1979. 224p.

BISOGNIN, D.A. et al. Quebra de dormência e de dominância apical em batata. Horticultura Brasileira, v.14, n.1, p.2326, 1996.

BISOGNIN, D.A. et al. Uso do ácido giberélico na quebra de dormência e de dominância apical em batata. Ciência Rural, v.28, n.2, p.205-213, 1998.

BISOGNIN, D.A. et al. Half-sib progeny evaluation and selection of potatoes resistant to the US 8 genotype of Phytophthora infestans from crosses between resistant and susceptible parents. Euphytica, v.125, p.129-138, 2002.

BRACKMANN, A. et al. Efeito da temperatura e condições de atmosfera controlada na armazenagem de maçãs 'Fuji' com incidência de pingo de mel. Revista Brasileira de Agrociência, v.8, n.1, p.37-42, 2002.

CONCEIÇÃO, A.M. da et al. Etanol para quebra de dormência em batata (Solanum tuberosum L.). Revista Brasileira de Agrociência, v.5, n.2, p.94-95, 1999.

FONTES, P.C.R.; FINGER, F.L. Dormência dos tubérculos, crescimento da parte aérea e tuberização da batateira. Informe Agropecuário, v.20, n.197, p.24-29, 1999.

ITTERSUM, M.K. van. Variation in the duration of tuber dormancy within a seed potato lot. Potato Research, v.35, p.261-269, 1992.

LECLERC, Y. et al. Microtuber dormancy in three potato cultivars. American Potato Journal, v.72, p.215-223, 1995.

LUND, D.G. et al. Efeito do etanol e ácido giberélico na superação da dormência em tubérculos de batata Bintje. Horticultura Brasileira, v.19, Supl, p.239, 2001.

PÓGI, M.C.; BRINHOLI, O. Efeitos da maturidade, do peso da batata-semente e da quebra da dormência sobre a cultivar de batata (Solanum tuberosum L.) Itararé (IAC 5986). Pesquisa Agropecuária Brasileira, v.30, n.11, p.1305-1311, 1995.

RABIE, K.A.E. et al. The role of some substances in regulating the interaction between endogenous gibberelins and abscisic acid in potato tubers. Annals of Agricultural Science, v.37, n.1, p.11-18, 1992. 
SCHOLTE, K. Breaking dormancy of seed potatoes. International Potato Course: production, storage and seed technology. Wagenigen : International Agricultural Centre, 1990. 4p.

SUTTLE, J.C. Involvement of ethylene in potato microtuber dormancy. Plant Physiology, v.118, p.843848, 1998.

SUTTLE, J.C. Postharvest changes in endogenous ABA levels and ABA metabolism in relation to dormancy in potato tubers. Physiologia Plantarum, v.95, p.233-240, 1995.
TURNBULL, C.G.N.; HANKE, D.E. The control of bud dormancy in potato tubers. Evidence for the primary role of cytokinins and a seasonal pattern of changing sensitivity to cytokinin. Planta, v.165, p.359-365, 1985.

WILTSHIRE, J.J.J.; COBB, A.H. A review of the physiology of potato tuber dormancy. Annual Applied Biologists, v.129, p.553-569, 1996.

WURR, D.C.E.; ALLEN, E.J. Effects of cold treatments on the sprout growth of three potato varieties. Journal of Agricultural Science of Cambridge, v.86, p.221-224, 1976. 